Opcration.-Sept. 2, 1011, the patient was given ether and a tourniquet upplied nt the wrist. A curved linear incision was made in the palm of the hani and the smull tumor was found at the center of the deep phlruar ards. On loosening up the tourniquet the tumor could be seen to pulsute plainly, and to increase to more than twice its size in the collapsed state. It was un aneurysm with a sinull perlicle, which was ensily ligated, and the whole sac removed.

'The patient male an uneventful recovery, and now has no difficulty at all in using this hand.

\section{A NEW TONSIL HOOK}

\section{J. I. I, (ONA, M.l). \\ ZANESVIII.F. 0 .}

I. have devised a new tonsil loook which seems to me an improvement over any that I have used. Its ailvantages are the following:

A snare can be slipped on or off the tonsil without changing the hold on the tonsil al'ter the hook is once placed.

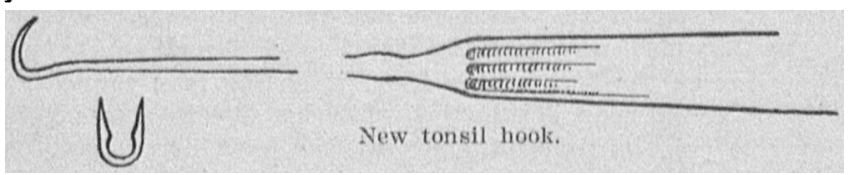

'T'le hook, once placed, will stay in place and not drop out when pressure is relaxed, as the slight thickening on the lower two-thirds of the inner surface of the prongs holds it in place.

(i01 Murket street.

\section{KNEE-JOIN'T AMPUTATIONS}

REPORT OF $\Lambda$ NEW METIIOD

\section{CIIARLES FATON PIIILLIPS, M.D.}

ANCON, CANAI, ZONE

To overcome the disadvantages of the thigh amputation, and to combine the good points and disadvantages of disarticulation with those of the osteoplastic operation, I have devised the following operntion:

An oval anterior and posterior flap are turned up, the former line of incision extending from the lower portion of the internal condyle downward, and anterior as far as the tuberosity of the tibia. 'The patella tenclon is cut without dissecting the skin from the patella and also leaving a portion of the patella tendon attached to the patella. 'The posterior flap is cut off approximately equal length or a little longer, if possible. 'The liamstring muscles are cut long. Inisarticulation is then completed by cutting the remaining structures. Vessels are ligated, nerves pulled down and cut short, and allowed to retract.

'The anterior flap is next turned up and the posterior surface of the patella sawed off. This is easily done by grasping the patella tendon by a pair of strong holding forceps when the patella can be sawed without difficulty, care being taken to remove as small a part of the patella as possible, so as to preserve nearly its original thickness.

Next, a small piece is sawed off each side (Fig. $1 \mathrm{~A} \mathrm{~A}$ ) in such a manner as will leave the patella narrower toward the upper end, or quadriceps uttachment, and also narrowed toward the anterior surface.

If it has been possible to preserve sufficient skin flaps to cover the stump, the next step is to saw into each side of the intercondyloid notch (Fig. $2 \mathrm{~A} \mathrm{~A}$ ) in such a manner that, when the piece of bone has been removed by means of a mallet and chisel (Fig. $2 \mathrm{~B}$ ), there is left a depression, or modified intercondy]oid notch, which is broacler at the bottom and also toward the popliteal space, or, in other words, narrower at the end of the bone and also toward the anterior surface. The bevel of the notch is made to conform as nenrly as possible to the bevel of the patella, but as there is of necessity a slight error, our aim should be to malie the bevel of the patella greater', or that of the notch less, so as to insure good apposition when the patella is fitted into position.

The patella is next grasped by a pair of strong boneholding forreps and drawn down forcibly until it slips into the place prepared for it and dovetails into it (Fig. $3)$. The greater the muscular pull, the more firmly it holds its place.

Next, the hamstring unuscles are sutured to the patella tendon. The skin is sutured, $\mathrm{a}$ small drain inserted and the leg put up in dressing. It will be found that the forcible drawing down of the patella brings the line of skin suture well to the poplitenl space and away fron all pressure.

If, however, it is impossible or inexpedient to savi enough skin to cover the stump without too great tension - and this can be determined by grasping and drawing

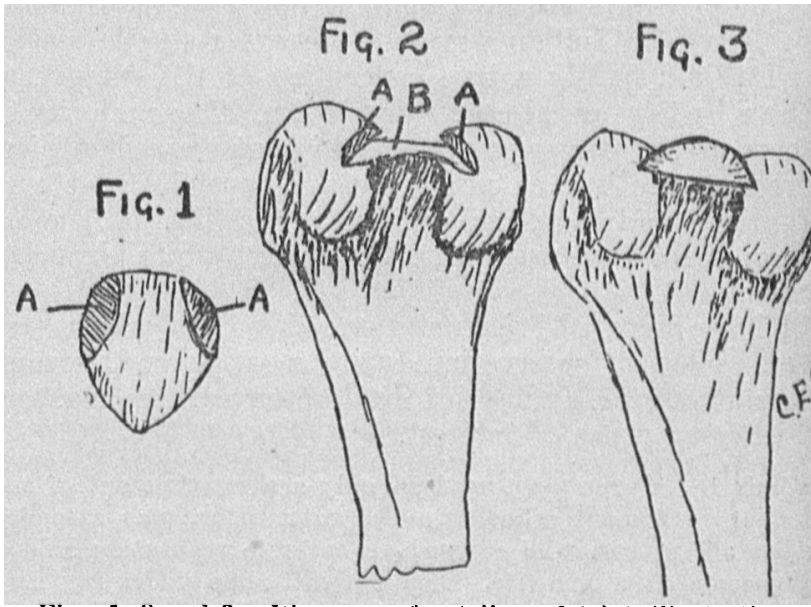

Figs, 1, 2 and 3.- blingrums of patella flnd jolnt, lllustrating ne method of knea-joint amputation.

the patella down before anything lins been done towar preparing the notch-equally good results may obtained by sawing through the condyles and then cul ting out a notch in the sawn condyles so that the patell will dovetail into it as beforc. Nearly 2 inches may $b$ gained in this way without sacrificing any of th advantages of the operation.

In either case we get a stump that is very satisfactory The patella forms the center of it, and laterally the $t w$ condyles share their portion of the weight in such manner that the normal distribution of weight, as in th. flexed knee, is preserved.

'The large bearing surface formed by the tough ski taken from the anterior aspect of the lince is able to tak the full weight of the body without abrasion or dis comfort.

Another advantage, which it shares in common witl disarticulation, or antputations below the knee, is th enlargement furnished by the condyles, or even portion of the condyles. With the enlargement, an artificial le can be adjusted so that it will not slip up and dow when walking or sitting.

Still another advantage which this operation possesse is the short flap which is sufficient to cover the stump 
this gain is made by forcibly drawing down the patella, bringing with it the skin fuscin nud museles, which, if nllowed to retract, would fail to cover a stmimp several inches shorter.

A representative of one of the largest artificial limb manufactories in the country remarled, after eareful examination of one of these amputations, that the st.mmp was ideal for the fitting and wearing of an artificial leg, and that it was by far the best end-bearing stump he had ever seen, and urged its ndoption in suitable cases, rom a prosthetic stand point.

The operation is not at all diffeult and requires very little additional time. The first time I crer attempted the operation it took about a half hour with closure and dressing.

The limits of usefulness of this operation, as with any, are narrow. No one would sacrifice $11 / 2$ or 2 inches of tibia needlessly, but where it is impossilile to save the knee, by this amputation all the benefits of a lince-bearing stump may be preserved.

Ancon Hospital.

\section{CASE OF INTUSSUSCWPTION OOMPIACATLI) BY Volvulus}

\section{S. J.AWIREN('H, M.l). WINATON-SAIR:M, N. C.}

$A$ careful search of the literature at my command has failed to reveal a case of intestinal olstrinction in which fle sy'mptoms and pathologic findings coincide with the following case:

Aug. 21, 1911, I first suw Mr. 33., white, nged 22, luborer. Family history was negative. P'atient had lmol usmul alisenses of childhood. He hal had attreks of severe pains in nblomen with nausea and vomiting at intervals of from one to sis montlas for the pust six years. Four yenrs ngo his appendix was removed, but this gave him no relief, and one of his nttacks came on $n$ few dnys after the operution. For the hast six montlis these attacks have increased in frequeney and Reverity.

Present Illucss.-Ahout 0 n. m. Aug. 20, 1011, while at breakfast, he was taken with one of his usmal attucks of nbdontinal pain, lie did not ant much breakfast, thinking the pain would pass olr, as usual, but it grew worse. 1le became mausented and vomited. A pliysiciun was enlled nud gave morphin to relieve the pain, but it failed; chloroform was given, but ns soon as the effect of the chloroform would wear off, the pain would come on ngnin with grent severity. An vomation soap and water was given with no result. 'The puin, nexting and constipution continued nll that lay and the V. b. M. Long. Itis condition wns ns follows: 1le was lying in facial on lis right side, thighs flexed on ubdomen, anxious rigid, expression, pulse 110, temperature $101 \mathrm{l}$.; aldomen could blighty clistended in upper part. On pulpution 4 mass () lu be felt helow and slightly to the left of the umbiliens. of the rect examination the mass could be folt nt the brim had pelvis, but it was not in the rectum. The patient liad cuema ge quantities of castor oil during the flay, and an tity of the evening, which was returued with n large gun!"lso volood, but no feenl matter or flatus. The patient luad If homited a dark fluid, which the father said smelled bad. had voided a small nmonnt of urine before I snw him.

Treatment.-Operation was decided on at onee. Under ether the peritomealicus and symphysis, was mule. On opening the escapeal cavity a lurge quantity of seropurulent fluid a mase. On passing the finger down to the brim of the prelvis corl, the could be felt nttached by what seemed to be a hard few soft mass langing over the polvie brim. There were a ew soft adhesions which were separated with the finger, und the mnss delivered, together with severnl coils of distended ileum. On examinntion, the mass was fouml to be an iliac intussusception which had become twisted on its mesenteric axis. The involved intestine was very hlack, so that it was considered unsafe to lenve it. The entire mass was resected and an end-to-rnd anastomosis made with the Murphy button, reinforced by silk lembert sutures. (imuze drains were pluced in the upper and lower ends of the incision. The pntient left the table in nlout thirty minutes: puise lobo.

Postoperative llistory.-lle received stryelmin, gr. 1/20, and 700 c.e. normal salt solntion under the skin while on the table. After being placed in bed morphin, gre. 1/4, and atropin, gr. 1/15n, was ndministered. One hour later the pulse was 140, respiration 34. The pulse gradunlly enme down to 110 at 6 a. m., temperature 99 $\mathrm{k}$. Butl, hegun to rise; morphin, gr. 1/1, atropin, gr. 1/150, was given and proctolysis started. Jatient passed gas. The stomach was distended and pationt vomited a dark fluid. The stomach-tulse was passed and a lurge quantity of gons and dark fluid mixed with oil was removed. The patient entinued to improve from this time on, the stomach being washed at intervals of from six to eight hours for the first forty-eiglit hours. Tho bowels moved freely thirty-six hours after the operntion. The patient voided urine freely and never had to be entheterized. Everything went smeothly until the fifth day when $I$ dressed the wound and removed the drain from the upper purt of the incision and placed in a fresh piece of gnuze in a vory small opening. In the afternoon the patient complnined of pmin in the ablomen sul his tomperature was found to be 103.2, pulse 120. (1) removal of the gawze a small quantity of purulent material was found. A small rubber tube wo inserted and the tempersture proniptly returned to normal. When the dressings were removed from the nbdominnl wound sixteen days after operation they were completely snturnted with n dark fluid, due to a feenl fistula discharging from the upper drainage tract. The small tube was removed; the fistula discharged profusely all day, but soon olosed and by the thind day there was not enough disclunge to soil the dressing through more than four layers of gauze. (O) September 18 pulient went home and was up and ubout the house; Septem. ber 26 he passed the button. At present, september 28 , he is ubout, looks well and feels well.

208 Masonic 'Temple.

\section{New and Nonofficial Remedies}

THE JOL,OWING MDITTONAT, ART'ICLES HAVE BHEN AOCHPTED

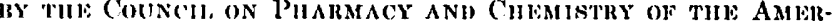

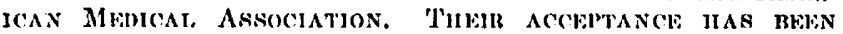

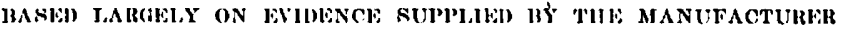
OB HIS AGEN'T ANI) IN PAR'T ON INVHS'THOATION MADE HY OR UNDER THE DIRECTION OF THE COUNCH. ('RITICISMS AND con-

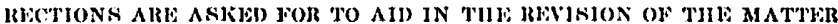

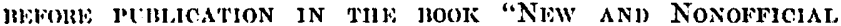
RwM limems."

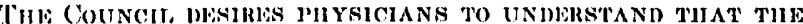

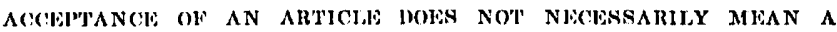
HHOMMENDATION, BUT THAT, SO FAR AS KNOWN, IT COMPLIES

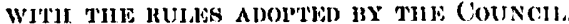

W. A. Puekner, Skcretary.

PROPAESIN-Propylis Aminobenzoas,-Propyl Aminobenzoatc.-Puramidobenzoic Acid Propyl Ester.-Propaesin, $\left.\mathrm{C}_{6} \mathrm{H}_{4} . \mathrm{NII}_{2} \mathrm{COO}\left(\mathrm{C}_{7} \mathrm{H}_{7}\right)\right]: 4$, is the propyl ester of paraminobenzoic acid, $\mathrm{C}_{83} \mathrm{H}_{4} \cdot \mathrm{NH}_{2} . \mathrm{COOH}, \mathrm{l}: 4$.

l'ropmesin is prepured by estritication of parnminobenzole neld whll propyl niecolul.

l'ropuesin is a fine, whlto or colorless, odolless, nenrly tasteless owwer. whleli prodices numbuess when plined on the tongue. froparesin is very milghtly solublo in water and is not rendily wetled by this solvent. It is soluble in nleohol, benzene, chloro-

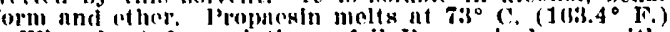

When hented on plutinum foll f'rophesln hurns without leaving nny ash; when henfed with an exeess of potnsslum hydroxide test solution it melts qofore bolling. formtng an olly luyer. By boiling

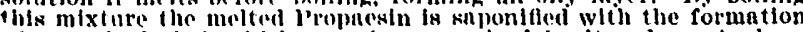
of propyl alcoliol, which may be recogntzed by its odor. A clear. 